\title{
Identifikasi Bakteri Escherichia coli 0157:H7 Pada Feses Penderita Diare dengan Metode Kultur dan PCR
}

\section{Vincentia Ade Rizky , Sa'adah Siregar ${ }^{1}$, Visensius Krisdianilo', Asvia Rahayu $^{1}$, Suventi Syafrina Ginting ${ }^{1}$, Kartini ${ }^{1}$}

Fakultas Farmasi, Institut Kesehatan Medistra lubuk Pakam, Jalan Sudirman

No. 38 Lubuk Pakam

e-mail: vincentiarizky@gmail.com

DOI $10.35451 /$ jfm.v3i2.615

\begin{abstract}
Escherichia coli 0157: H7 is the main cause of foodborne disease in several countries, one of which is diarrhea. The problem that often occurs in Indonesia that requires treatment and study from various aspects is Diarrhea. The conventional method of laboratory examination such as culture is a method that is often carried out, but in making the diagnosis requires a long time, the number of samples is large, and the results are less accurate because contamination can occur. Another more accurate technique for detection E. coli 0157: H7 is the PCR technique. This study aims to identify the Escherichia coli O157: H7 bacteria by culture method and PCR. The results showed that the culture method and PCR of 8 isolated samples 4 showed positive results for the bacteria E. coli O157: H7. However, the PCR method is more selective and the time used is faster than the culture method.
\end{abstract}

Keywords: Escherichia coli O157:H7, PCR, Culture method

\section{PENDAhUlUAN}

Infeksi merupakan penyebab utama penyakit di dunia terutama di daerah tropis, seperti Indonesia (Hermayudi \& Ayu, 2017). Agen penyebab infeksi antara lain bakteri Escherichia coli yang merupakan bakteri komensal atau flora normal di peritoneum atau usus bagian bawah (Elliott et al., 2013). Bakteri E. coli akan bersifat patogen apabila berada ditempat yang bukan habitatnya (Brooks et al., 2005).

Bakteri $E$. coli dapat mengeluarkan racun sehingga menjadi patogen dan menyebabkan penyakit. Bakteri E.coli dapat memproduksi racun yang dapat menimbulkan penyakit, salah satu racun yang paling sering teridentifikasi adalah Shiga Toxinproducing Escherichia coli (STEC) yaitu pada bakteri E. Coli serotype 0157:H7. (Jawetz et al., 2010; Rananda et al., 2016).

Bakteri E. coli 0157:H7 merupakan penyebab utama foodborne disease di beberapa negara. Berdasarkan laporan dari CDC tentang insiden infeksi Escherichia coli O157:H7 menyatakan bahwa 8.598 kasus pada 49 negara terserang wabah penyakit 
yang disebabkan oleh bakteri ini. Sebanyak 1.493 (17\%) kasus, penderit masuk rumah sakit, 254 (4\%) penderita teridentifikasi mengalami HUS (Hemolytic Uremic Syndrome), dan 40 $(0,5 \%)$ kasus penderita meninggal. Selain itu di negara Prancis, terdapat 69 orang terinfeksi bakteri E. coli O157:H7 dan 17 orang menderita HUS. Kasus HUS di Argentina berhubungan dengan infeksi bakteri $E$. coli O157:H7 yang mencapai 400 kasus per tahunnya. Penelitian sebelumnya oleh Sartika et al. (2005) yang menunjukkan bahwa daging sapi $(100 \%)$ dan susu sapi $(73 \%)$ terkontaminasi oleh bakteri $E$. coli O157:H7 yang kemudian dikonsumsi oleh manusia sehingga menyebabkan penyakit diare.

Pada manusia, infeksi akibat bakteri jenis ini ada yang tidak menimbulkan gejala (asimtomatis) ataupun timbul gejala berupa diare berdarah ataupun diare tanpa darah (Dutta et al., 2011; Peter et al., 2011).

Pemeriksaan laboratorium metode konvensional seperti kultur merupakan metode yang sering dilakukan, akan tetapi dalam menegakan diagnosa butuh waktu dan umlah sampel yang banyak, serta hasil kurang akurat karena dapat terjadi kontaminasi. Teknik lain yang lebih akurat untuk mendeteksi E. coli 0157:H7 adalah dengan teknik PCR.

Penelitian sebelumnya Bakri et al., (2010) menyatakan bahwa pasien ana (0-14 tahun) yang menderita diare dari kultur teridentifikasi sebanyak $21,42 \%$ bakteri E.coli O157:H7 dan 46,43\% menggunakan PCR. Maka dari itu peneliti ingin meneliti kembali tentang deteksi bakteri E. coli 0157:H7 metode kultur dan PCR.

\section{METODE PENELITIAN}

Jenis penelitian ini adalah Penelitian Experimental yang dilakukan di Lab. Mikrobiologi dan Biologi Molekuler Institut Kesehatan Medistra Lubuk Pakam pada bulan November 2020. Sampel penelitian ialah feses penderita diare.

Alat - alat yang digunakan antara lain tabung reaksi, Erlenmeyer, gelas ukur, cawan petri, batang ose, rak tabung, bunsen, kapas steril, Laminal Air Flow, timbangan analitik, neraca analitik, kulkas, perangkat uv, elektroforesis, PCR, spin colomn, mini cup, dll. Bahan - bahan yang digunakan dalam penelitian ini adalah spesimen medium transport Cary-Blair, BHIB, NA, SSA, Sorbitol Mac Conkey Agar, media Peptone Water (indol), media Methyl Red-Voges Proskauer, media simons citrate, reagen kit QIAmp, dll.

\section{Kultur Bakteri}

Sampel dalam medium transport Carry-Blair diinokulasikan ke medium pengaya (media BHIB) dan diinkubasi pada suhu $37^{\circ} \mathrm{C}$ selama $18-24$ jam.

Selanjutnya sebanyak 1 ose kemudian diinokulasikan ke dalam cawan petri yang berisi media NA, SSA, Sorbitol Mac Conkey Agar (SMCA) selanjutnya dinkubasi $\pm 18-24$ jam pada suhu $37^{\circ} \mathrm{C}$ kemudian diamati pertumbuhannya.

Bakteri yang telah tumbuh pada media isolasi yaitu dengan pemeriksaan secara mikroskopis untuk

menentukan sifat atau ciri hasil kultur pada media bakteri dan dilanjutkan dengan uji biokimia.

\section{Uji Mikroskopis}


Identifikasi mikroskopis dengan cara membuat sediaan kemudian dilakukan pewarnaan gram. Bakteri berwarna merah merupakan Bakteri Gram (-) serta bakteri berwarna ungu adalah bakteri Gram (+).

\section{Uji Biokimia}

Identifikasi bakteri dilanjutkan dengan tes biokimia IMVIC yaitu pengujian pada media Indol Metil Red (MR), Vogas Proskauer (VP), dan uji sitrat. Media ini ditanam bakteri kemudian dinkubasi pada suhu $37^{\circ} \mathrm{C} \quad \pm 18-24$ jam. Kemudian dilakukan identifikasi bakteri untuk lebih memastikan bahwa yang tumbuh adalah bakteri tersebut, dan pengamatannya disesuaikan dengan rujukan buku.

\section{Identifikasi Molekuler}

Sebanyak $100 \mu$ isolate bakteri $E$. coli positif pada media cair dimasukkan ke dalam tabung Eppendorf sebanyak 2 $\mathrm{mL}$ kemudian dilakukan centrifugasi pada kecepatan $5.000 \mathrm{rpm}$ selama 5 menit pada suhu $5^{\circ} \mathrm{C}$. Massa sel yang diperoleh selanjutnya ditambahkan TE buffer $\mathrm{pH} 8$, dan dilakukan pelisisan dengan menggunakan larutan yang mengandung $1 \%$ Triton X-100 (Sigma) dalam buffer TE $\mathrm{pH}$ 8. Proses ini dilakukan dengan pemanasan pada air mendidih selama 15 menit dan selanjutnya dibekukan dengan cara disimpan pada suhu $20^{\circ} \mathrm{C}$ selama 15 menit. Lakukan proses Pemanasan dan pembekuan sebanyak 3 kali pengulangan. Primer yang digunakan adalah shiga like toxin tipe I (Stx1): LP30: CAG TTA ATG TGG TGG CGA AGG dan LP-31: CAC CAG ACA ATG TAA CCG CTG: shiga like toxin tipe II (Stx2) dengan pasangan primer LP43: ATC CTA TTC CCG GGA GTT TACG dengan LP-44: GCG TCA TCG TAT ACA CAG GAG C dengan ukuran produk PCR yang akan dihasilkan untuk gen stx1 dan stx2 berturut-turut 348bp dan 584bp. Proses PCR diperoleh dari larutan dengan volume total $12,5 \mu \mathrm{l}$ yang terdiri dari dNTPs $10 \mathrm{mM}$, primer forward sebanyak $25 \mathrm{nmol}$ dan reserve $25 \mathrm{nmol}$, Buffer II $1 \mathrm{x}, \mathrm{MgCl}_{2} 75 \mathrm{mM}$, Amplitaq 0,45 U dan DNA sebanyak $1 \mu \mathrm{l}$. Tahapan amplifikasi meliputi $1 \mathrm{x}$ Siklus pada suhu $94^{\circ} \mathrm{C}$ selama 5 menit, lalu $40 x$ Siklus suhu $94^{\circ} \mathrm{C}$ selama 30 detik, dan $48^{\circ} \mathrm{C}$ selama 30 detik dan $72{ }^{\circ} \mathrm{C}$ selama 30 detik. Terakhir 1x Siklus $72{ }^{\circ} \mathrm{C}$ selama 5 ment.

Hasil dari amplifikasi PCR selanjutna dilakukan elektroforesis menggunakan $1 \%$ agarose dan TAE Buffer. Kemudian ditambahkan pewarna EtBr. Selanjutnya divisualisasikan dengan sinar UV illuminator dan didokumentasikan.

\section{HASIL DAN PEMBAHASAN}

yang dilakukan secara kultur, didapatkan bahwa dari ke-8 sampel yang dilakukan pemeriksaan didapatkan hasil positif Escherichia coli 0157:H7 sebanyak 4 sampel. Hal ini ditunjukkans pada tabel 1 dari hasil pemeriksaan mikroskopis dan biokimia yang selanjutnya dibandingkan dalam buku Bergey's Manual of Systematic Bacteriology.

Tabel 1. Hasil Pemeriskaan Mikroskopis dan Biokimia

\begin{tabular}{|c|c|c|c|c|c|c|}
\hline \multirow[b]{2}{*}{$\underset{I}{\text { Sampe }}$} & \multirow[b]{2}{*}{$\begin{array}{l}\text { Mikroskopi } \\
\text { s }\end{array}$} & \multirow[b]{2}{*}{ SMCA } & \multicolumn{4}{|c|}{ Uji Biokimia } \\
\hline & & & $\begin{array}{c}\text { Indo } \\
1\end{array}$ & $\begin{array}{l}M \\
R\end{array}$ & $\begin{array}{l}\text { V } \\
P\end{array}$ & $\begin{array}{l}\mathrm{S} \\
\mathrm{C}\end{array}$ \\
\hline$F 2$ & $\begin{array}{l}\text { Gram (-) } \\
\text { Bacil }(+)\end{array}$ & $\begin{array}{c}\text { Jernih } \\
\text { (tidak } \\
\text { Berwarna } \\
\text { ) }\end{array}$ & + & + & - & - \\
\hline F3 & $\begin{array}{l}\text { Gram }(-) \\
\text { Bacil }(+)\end{array}$ & $\begin{array}{c}\text { Jernih } \\
\text { (tidak } \\
\text { Berwarna } \\
\text { ) }\end{array}$ & + & + & - & - \\
\hline F4 & $\begin{array}{l}\text { Gram (-) } \\
\text { Bacil }(+)\end{array}$ & $\begin{array}{c}\text { Jernih } \\
\text { (tidak } \\
\text { Berwarna } \\
\text { ) }\end{array}$ & + & + & - & - \\
\hline
\end{tabular}




\begin{tabular}{|c|c|c|c|c|c|}
\hline F5 & $\begin{array}{l}\text { Gram (-) } \\
\text { Bacil (+) }\end{array}$ & $\begin{array}{c}\text { Jernih } \\
\text { (tidak } \\
\text { Berwarna } \\
\text { ) }\end{array}$ & + & + & - \\
\hline F6 & $\begin{array}{l}\text { Gram (-) } \\
\text { Bacil (+) }\end{array}$ & $\begin{array}{c}\text { Berwarna } \\
\text { Merah } \\
\text { Muda }\end{array}$ & - & - & + \\
\hline F7 & $\begin{array}{l}\text { Gram (-) } \\
\text { Bacil (+) }\end{array}$ & $\begin{array}{c}\text { Berwarna } \\
\text { Merah } \\
\text { Muda }\end{array}$ & + & - & + \\
\hline F8 & $\begin{array}{l}\text { Gram (-) } \\
\text { Bacil (+) }\end{array}$ & $\begin{array}{c}\text { Berwarna } \\
\text { Merah } \\
\text { Muda }\end{array}$ & - & - & - \\
\hline F9 & $\begin{array}{l}\text { Gram (-) } \\
\text { Bacil (+) }\end{array}$ & $\begin{array}{c}\text { Berwarna } \\
\text { Merah } \\
\text { Muda }\end{array}$ & + & + & - \\
\hline
\end{tabular}

Identifikasi secara mikroskopis yang ditunjukkan pada gambar 1 ditemukan bakteri gram (-) bacil (+) yang artinya bakteri berbentuk batang pendek lurus (cocobacil) berwarna merah. Hal ini dinyatakan pula dalam penelitian Jaipah et al., (2017) bahwa bakteri eschericia coli adlah bakteri gram (-) berbentuk batang pendek lurus atau disebut juga dengan kokobasil. Pada saat dilakukan pewarnaan gram, bakteri E. coli tidak menyerap warna kristal violet, melainkan menyerap warna merah dari safranin (Rizky, 2018).

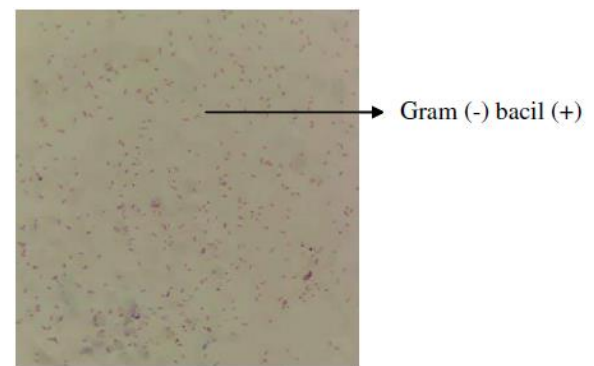

Gambar 1. Hasil Mikroskopis Sampel F2

Pemeriksaan mikroskopis tidak cukup untuk mengidentifikasi bakteri Escherichia coli 0157:H7, maka dari itu dilakukan uji SMCA dan biokimia sebagai uji konfirmasi. Berdasarkan hasil penelitian uji biokimia (gambar 2) dan SMCA terdapat 4 sampel yang menunjukan bahwa sampel tersebut teridentifikasi bakteri E. coli O157:H7. Hal ini didasarkan pada hasil peneltiian uji biokimia dan SMCA yang secara berturut menunjukkan hasil : Indol $(+)$, MR $(+)$, VP $(-)$, Simons citrate $(-)$, dan SMCA jernih. Hasil dari media SMCA menunjukkan koloni berwarna jernih yang menandakan bahwa bakteri tersebut tidak dapat memfermentasi sorbitol dan bersifat motil (O157:H7). Kultur SMCA merupakan media yang digunakan untuk mengidentifikasi $E$. coli serotiper 0157:H7. Sorbitol digunakan sebagai penanda atau media isolasi utama dalam mendeteksi bakteri jenis ini (Hidayati et al., 2018)

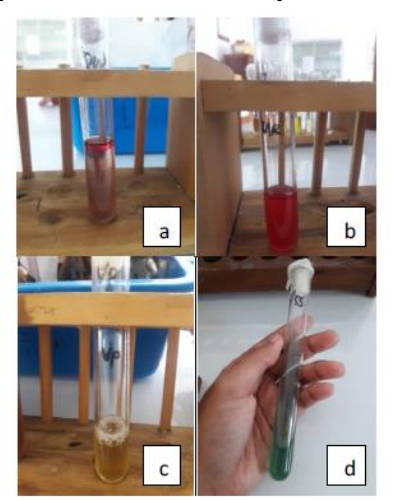

Gambar 2. Hasil Uji Biokimia Sampel F2 yang secara berurut: a) Uji Indol; b) Uji Methyl Red (MR); c) Uji Voges Proskauer (VP); d) Uji Simon's Citrate

Hasil uji PCR pada pita fragmen dengan ukuran 123 bp menunjukkan bahwa sampel F2,F3,F4 dan F5 terdapat bakteri Escherichia coli O157:H7, sedangkan pada sampel yang lain tidak ditemukan bakteri ini (Gambar 3).

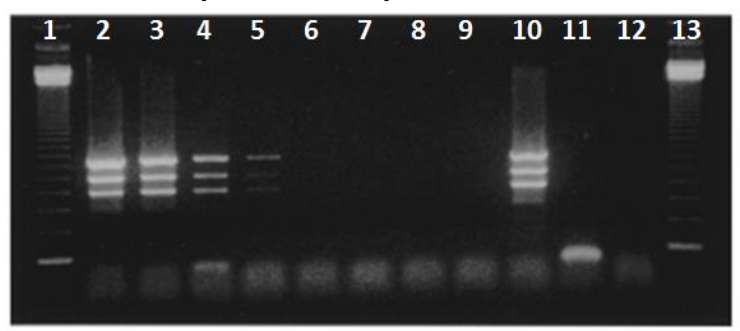


Gambar 3. Hasil Pemeriksaan Elektroforesis yang menunjukkan amplifikasi DNA multipleks PCR yang telah diekstraksi, secara berurut: Jalur 1\&13 Marker DNA 123-bp; Jalur 2-9 Sampel; Jalur 10 Positif kontrol strain Escherichia coli O157:H7; Jalur 11 Negatif kontrol Escherichia coli ATCC 25922.

Hasil pemeriksaan PCR telah terbukti spesifik dalam mendeteksi bakteri E. coli serotipe O157:H7. Metode PCR merupakan salah satu metode molekuler yang telah banyak menjadi pilihan klinis beberapa tahun terakhir. Metode ini memiliki tingkat sensivitas yang sama atau lebih besar dari pemeriksaan kultur. Pada penelitian ini metode PCR dengan menggunakan primer Escherichia coli 0157:H7 mampu mendekteksi keberadaan bakteri ini dengan waktu yang lebih cepat yaitu selama 1 hari, sedangkan metode kultur membutuhkan waktu yang cukup lama yaitu sekitar 5-6 hari. Hal ini sejalan dengan penelitian yang telah dilakukan Morin et al., (2004) yang melaporkan bahwa deteksi bakteri Escherichia coli O157:H7, Vibrio Cholera dan Salmonella typhi menggunakan metode PCR mampu mendeteksi dan mengidentifikasi bakteri pathogen baik pada sampel klinik, air, maupun makanan (Jayanti, 2018).

\section{KESIMPULAN}

Berdasarkan hasil penelitian dan dibandingkan dengan penelitian lain dapat disimpulkan bahwa teknik identifikasi bakteri Escherichia coli 0157:H7 dalam feses penderita diare dengan menggunakan metode molekuler yaitu PCR sudah terbukti lebih sensitif dan hasil yang dikeluarkan relative cepat namun dengan biaya yang mahal jika dibandingkan dengan metode konvensional. Oleh karena itu dapat direkomendasikan dan digunakan oleh tenaga kesehatan dalam mendeteksi dini sehingga akan membantu penegakan diagnosa lebih cepat dan menentukan pengobatan secara lebih efektif.

\section{DAFTAR PUSTAKA}

Bakri Z, Hatta M \& Nasrum M. (2010). DETEKSI BAKTERI ESCHERICHIA COH O157:H7 PADA FESES PENDERITA DIARE DENGAN METODE KULTUR DAN PCR. JST Kesehatan; (5), 2:184-192

Brooks GF, Butel JS, Morse SA (2005). Mikrobiologi Kedokteran Jawetz, Melnick, dan Adelberg. Edi Nugroho (alih bahasa). Jakarta : Salemba Medika

Dutta T.K., Roychoudhury S.P., Bandyopadhyay Wani S.A., and I. Hussain. (2011). DETECTION AND CHARACTERIZATION OF SHIGA TOXIN PRODUCING ESCHERICHIA COLI (STEC) \& ENTEROPATHOGENIC

ESCHERICHIA COLI (EPEC) IN POULTRY BIRDS WITH DIARRHOEA. Indian J. Med. Res; 133: 541-545.

Elliott T, Worthington T, Osman H, Gill M (2013). Mikrobiologi Kedokteran \& Infeksi Edisi 4. Jakarta : EGC

Hermayudi dan Ayu, P.A. (2017). Penyakit daerah tropis. Yogyakarta: 2017.

Hidayatu W., Temaja I.G.R.M., dan Fatmawati N.N.D. (2018). KARAKTERISTIK FENOTIP ISOLAT KLINIK ESCHERICHIA COLI O157:H7 PADA MEDIA SORBITOL MAC CONKEY AGAR (SMAC). J. Agric.Sci. and Biotechnol, 7 (1).

Jaipah N, Saraswati I, Hapsari R (2017). UJI EFEKTIFITAS ANTIMIKROBA EKSTRAK BIJI 
PEPAYA (CARICA PAPAYA L.) TERHADAP PERTUMBUHAN ESCHERICHIA COLI SECARA IN VITRO. Jurnal Kedokteran Diponegoro, ISSN : 2540 8844,6 (2)

Jawetz, M. A. (2010). Mikrobiologi Kedokteran. (25 ed). (G. F. Brooks, K. C. Carroll, J. S. Butel, S. A. Morse, T. A. Mietzner, Penyunt, A. W. Nugroho, D. Ramadhani, $\mathrm{H}$. Santasa, N. Yasdelita, \& K. W. Nimala, penerj). New York: Mc Graw Hill.

Jayanti, D. D. (2018). DETEKSI ESCHERICHIA COLI O157 PADA BERBAGAI AIR MINUM DI KELURAHAN SEKARAN GUNUNG PATI SEMARANG. Universitas Negeri Semarang

Morin NJ, Gong Z \& Li XF. 2004. REVERSE TRANSCRIPTIONMULTIPLEX PCR ASSAY FOR SIMULTANEOUS DETECTION OF ESCHERICHIA COLI O157: H7, VIBRIO CHOLERAE OI, AND SALMONELLA TYPHI. Clinical Chemistry. 50(11): 2037-2044.

Peter C.H., Councell F.T., Keys C., and Monday S.R. (2011). VIRULENCE CHARACTERIZATION OF SHIGA-TOXIGENIC ESCHERICHIA COLI ISOLATES FROM WHOLESALE PRODUCE. Appl. Environ. Microbiol. 77 (1): 343-345.

Rananda RM, Djamal A, Julizar. 2016. IDENTIFIKASI BAKTERI ESCHERICHIA COLI O157:H7 DALAM DAGING SAPI YANG BERASAL DARI RUMAH POTONG HEWAN LUBUK BUAYA. Jurnal Kesehatan Andalas, 5(3): 614-617

Rizky, V. A. (2018). PERBEDAAN JUMLAH KOLONI BAKTERI

\section{ESCHERICHIA COLI PADA PENANAMAN MENGGUNAKAN TEKNIK SENGKELIT (CALIBRATED LOOP) DAN MIKROPIPET (PIPET DILUTION METHOD) METODE SPREAD PLATE. UKMC Palembang}

Sartika, Indrawani, dan Sudiarti. (2005). ANALISIS MIKROBIOLOGI ESCHERICHIA COLI 0157:H7 PADA HASIL OLAHAN HEWAN SAPI DALAM PROSES PRODUKSINYA. Jurnal Makara Kesehatan, 9 (1): 2328.

Vos, P. et al. (2009). BERGEY'S MANUAL OF SYSTEMATIC BACTERIOLOGY. 2nd edn, Springer-Verlag New York. 2nd edn. Springer-Verlag New York. doi: 10.1007/978-0-38768489-5. 